\title{
The Effectiveness of Novo Learning System and Self Directed Learning toward the English Ability of Non- English Program Students
}

\author{
Melda Agnes Manuhutu \\ Victory University of Sorong \\ Indonesia
}

\author{
Tagor Manurung \\ Victory University of Sorong \\ Indonesia
}

\author{
Lulu Jola Uktolseja \\ Victory University of Sorong \\ Indonesia
}

\author{
Jalmijn Tindage \\ Victory University of Sorong \\ Indonesia
}

\author{
Berti Pakaila \\ Victory University of Sorong \\ Indonesia
}

\begin{abstract}
The purpose of this study is to identify, explore and compare: correlations between: (1) the use of novo learning and English language skills in non-English students at Victory Sorong University; (2) the relationship between independent learning and English language skills in non-English students at Victory Sorong University; (3) the relationship between the use of novo learning and joint learning independence of English language skills in non-English students at Victory Sorong University. Data obtained by questionnaire. Based on the analysis and discussion of data, the following conclusions can be drawn: (1) There is a positive relationship between the use of novo learning and English language skills in non-English students at Victory Sorong University. This can be proven by the result of significant product moment correlation analysis of $5 \%$. tcount $>$ ttable or $3,848>1,694$; (2) There is no relationship between independent learning and English language skills in non-English students at Victory Sorong University. This can be proven by the result of significant product moment correlation analysis of $5 \%$. tcount $<$ ttable or $1,325<1,694$; (3) There is a positive relationship between the use of novo learning and self-directed learning together on the ability of English in non-English students at Victory Sorong University. This can be proved by the results of a significant product moment correlation analysis of $5 \%$. Fcount $>$ Ftable or 24,959> 3,316 with the regression line equation $\mathrm{Y}=6,853+$ O.427X_1 + 0.159X_2.
\end{abstract}

\section{General Terms}

Information System

\section{Keywords}

Novo Learning System, Self-Directed Learning, Achievement

\section{INTRODUCTION}

In this present age, the growth of technology and science delivers life easily. They can get access to the information within a second.Any advancement of technology presents theory or constructs, and realistic insights in the development and enhancement of knowledge, skills, and attitudes among students and teachers [1].Technological developments in industrial 4.0 must be welcomed responsibly. Industrial Revolution 4.0, all processes are carried out in an automated system in all activation processes, where the development of internet technology is increasingly developing and can connect people throughout the world. The development of information technology is rapidly happening now that automation is happening in all fields, new technologies and approaches that combine in real, digital and fundamentally [2]. Throughout this development, the world of education as a strategic position for the progress of the nation needs to adapt technology-based learning which has previously been carried out by many other developed countries in the world. The learning process in this era is indeed very developed and advanced, but this must also be encouraged by good control from each responsible party such as parents, teachers and students themselves. Moreover, without the cooperation of all parties, the various existing technological tools cannot be utilized properly and correctly. Thus, the expected results also cannot be achieved to the maximum. Studying with the internet is no longer a taboo thing. Internet is a very popular application with maximum access at a low cost. It is used widely this day as the tool of education to access information or even share information to the other people. The internet used for learning will increase the ability to read, think critically, and integrate or associate reading resources with one another [3]. Education in the past centered on educators, which educators are the only source of learning for students. The internet can also enhance the integration capabilities of different information sources (for example linking information from different web pages) and evaluating information by evaluating the credibility of recommendations on web pages [4]. This is what supports the creation of student centered learning and students can learn independently. Through Belmawa, the Ministry of Education and Culture initiated an Android-based application that is supported by the internet using a mobile phone, the Novo Learning system to help students who are from non-English study programs to study English independently and intensively. The ease of accessing material anywhere and anytime is an advantage of this application. Students who always use the internet for lecture activities as one of the media in learning activities, will support the quality of education and the quality of learning. This is in accordance with Cobine's opinion [5] that "Through independent study, students become doers, as well as thinkers", this statement means that the use of the internet as a learning medium conditions students to learn independently. The quality of education is measured and assessed on student learning outcomes as well as student learning practices at school [6].Students must be able to think of a good reason to be able to balance the development of an increasingly competitive world of education [7].Identified as a multidimensional structure that includes the meaning of life, positive relationships, responsibilities, positive feelings, and 
success [8].Activities and assignments used in teaching must help spark the interest of new students and offer more challenges and autonomy to develop student interests that develop in certain directions [9].Novo learning system is present as an approach to education today, to eliminate the scourge of fear from learning English, and to arouse enthusiasm and motivation for continuous learning wherever and whenever. In this research, Novo learning as an application is given to students of an Information System program to learn English independently. This study aims to explain the effect of the novo learning system and selfdirected learning on English learning achievement of nonEnglish language students.

\section{LITERATURE REVIEW}

In this section will be discussed about the general definition of the key terms included novo learning system, self-directed learning and English students' ability.

\subsection{Novo Learning}

Novo learning system is the part of information system in android based. An information system is a system within an organization coordinated by resources to change input (data) in order to reach the target. Novo learning system can be accessed by any kinds of gadget such as hand phone, tablet or laptop. This system has two actors; they are player (students) and admin (lecturer). The students can access this system by download it via app-store or play-store by name Novo Player while the admin can access it by open the source of Novo Studio.

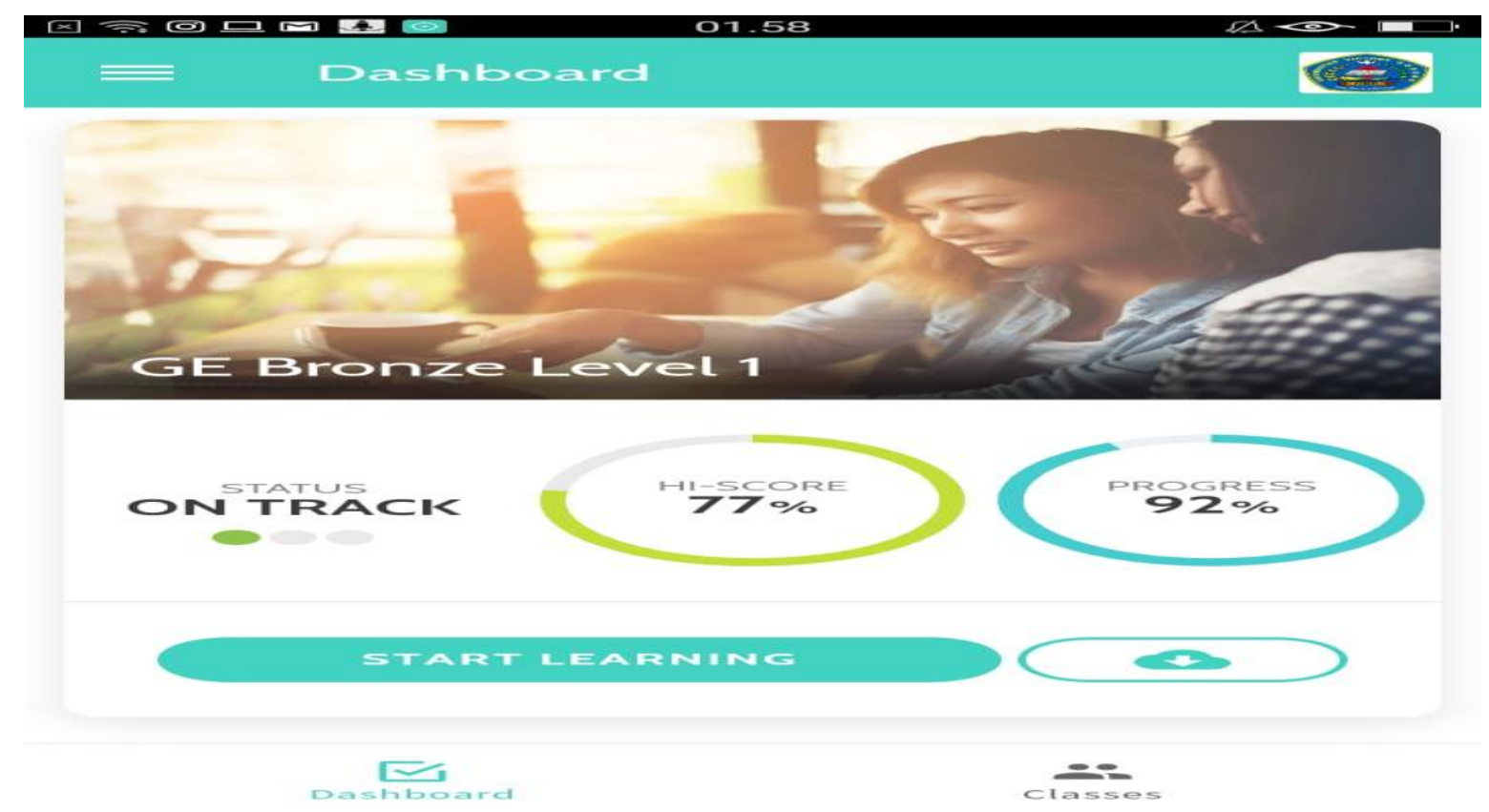

Fig 1: The Interface of Novo-Player

II. Reports CONTENT

Fig 2: The Interface of Novo-Studio 


\subsection{Self-Directed Learning}

Independent learning (SDL) is a teaching method which is increasingly used in adult education in universities [10]. Individuals who have high Self-Directed Learning (SDL) are proactive individuals, have their own initiative, have a lot of sense, and become individuals who have responsibilities to always learning [11].

\section{METHOD}

\subsection{Design of Research}

This research used a descriptive method with the correlation approach. Descriptive method is a method used to find the elements, characteristics, characteristics of a phenomenon [12]. This method starts with collecting data, analyzing and interpreting data. Whereas the purpose of the correlational approach is to investigate the variation of factors associated with variations of other factors based on the correlation coefficient. In research or inquiry, the role of data collection techniques is very important to help researchers obtain accurate and accurate data. Each data collection technique or method has different characteristics with each of the advantages and disadvantages. There are several techniques that can be used by researchers to collect research data. Among them: (1) interview techniques, (2) observation, (3) questionnaire techniques, (4) technical documentation, and (5) test techniques [13]. Based on the problems in this study about the effectiveness of the Novo Learning System on English learning of non-English language students at Victory Sorong University, the method or technique deemed appropriate in this study is through questionnaires and the final results of tests on the Novo system. A list of questions is a list where each question has provided answers to be chosen, or provided a place to fill in the answers [14]. It can be concluded that the definition of the questionnaire is a set of systematic written questions that provide appropriate answers to select or provide a place to fill in the answers and the list of questions is distributed to all respondents to obtain information provided to collect accurate data. In this questionnaire technique we found one independent variable, the Novo learning system (X1) and self-directed learning.(X2) and one dependent variable, English ability (Y). There are several reasons why researchers use questionnaires:

1. The requested data related to students' personal problems is about their perceptions after using the novo learning system and also about their personal values or achievements. So researchers believe with the questionnaire, researchers can take honest or true perceptions, opinions or answers.

2. Time and energy limitations, with the questionnaire data can be collected together at the same time and obtained simultaneously as expected.

The sample is part of the number and characteristics of the population [15]. The sampling must be done carefully with the right technique for the existence of the sample to truly represent the population. In this study, researchers took 33 samples which constitute the entire population of Novo learning wave one participants coming from the information systems study program.In this study a Likert scale with a checklist form as an instrument for measuring questionnaire items. The answer to each item that uses a Likert scale has a gradation from truly positive to negative, and each answer has its own value. If the character of the statement leads to something positive, the alternative answer "strongly agree" will have a high value. But if the statement leads to a negative thing, the answer "strongly agree" will have a low value. The following is a Likert scale as a list of questionnaire scores.

Table 1: Likert Scale

\begin{tabular}{|c|c|c|}
\hline Statement & Positive & Negative \\
\hline Strongly Agree & 4 & 1 \\
\hline Agree & 3 & 2 \\
\hline Disagree & 2 & 3 \\
\hline Strongly Disagree & 1 & 4 \\
\hline
\end{tabular}

There are two concepts to measure data quality, namely reliability and validity. Validity and reliability tests are used to test data using a questionnaire to see questions in filling out the questionnaire by respondents valid or not in taking data [15]. Thus, a valid and reliable instrument is a requirement for retrieving valid and reliable data. Based on the explanation, validity and reliability tests are needed to test the validity and reliability of the questionnaire used to collect data in this study.

The raw data collected by researchers will not be useful if not analyzed [16]. Data analysis is a very important part of the scientific method, because with analysis, data can have meanings and meanings that are useful in solving research problems. Based on the hypotheses and variables in this study, data analysis that is relevant for this study is multiple linear regression. Multiple linear regression is a regression that has one dependent variable and one or two independent variables [15]. Multiple linear regression is performed if the functional relationship parameters between one dependent variable with more than one variable will be as predicted, then the regression analysis is carried out in connection with multiple regression and also hypothesis testing.

\subsection{Multiple Linear Regression Model}

This analysis is used to determine the relationship of Novo learning system and self-directed learning on English ability. The multiple linear regression model in the formula is as follows:

$$
\begin{aligned}
\mathrm{Y} & =\text { English Ability } \\
\mathrm{a} & =\text { Constant } \\
\mathrm{b} 1 & =\text { First regression coefficient } \\
\mathrm{b} 2 & =\text { Second regression coefficient } \\
\mathrm{X} 1 & =\text { Novo Learning System } \\
\mathrm{X} 2 & =\text { Self-Directed Learning }
\end{aligned}
$$

\subsubsection{Simultaneous Test (Test F)}

Simultaneous Test is intended to determine whether all independent variables have the same effect on the dependent variable. Tests carried out using the $F$ test. If $F$ arithmetic $>F$ table then the result is rejecting the null hypothesis and accepting alternative hypotheses, which together affect the dependent variable.

\subsubsection{Partial Test (T Test)}

Partial test or regression coefficient is intended to determine whether the independent variables included in the equation individually affect the value of the dependent variable using the $t$ test. Decision making by comparing $t$ arithmetic with $t$ table. 


\subsection{Testing Prerequisite Analysis}

Before analyzing data, there are several tests that must be done before. They are a validity and reliability test.

\subsubsection{Validity Test}

\subsubsection{Novo-Learning System Questionnaire}

This questionnaire was given to 33 respondents with 10 questions. This testing criterion is to compare the value or degree of freedom in this calculation is 0.296 (DF = 33-2). Based on the calculation of this validity test, there are two questions that have a lower value. These questions are questions number 2 and 3 . So these questions, will not be used in hypothesis testing.

This questionnaire was given to 33 respondents with 10 questions. This testing criterion is to compare the value or degree of freedom in this calculation is $0.296(\mathrm{DF}=33-2)$. Based on the calculation of this validity test, there are two questions that have a lower value. These questions are questions number 2 and 3. So these questions, will not be used in hypothesis testing.

Table 2: Validity Test of Novo Learning

\begin{tabular}{|c|c|c|}
\hline Numbers & Thevalue of & Explanation \\
\hline number1 & 0.431 & Valid \\
\hline number2 & 0.289 & Invalid \\
\hline number3 & 0.234 & Invalid \\
\hline number4 & 0.581 & Valid \\
\hline number5 & 0.614 & Valid \\
\hline number6 & 0.379 & Valid \\
\hline number7 & 0.525 & Valid \\
\hline number8 & 0.441 & Valid \\
\hline number9 & 0.354 & Valid \\
\hline number10 & 0.671 & Valid \\
\hline
\end{tabular}

\subsubsection{Self-Directed Learning Questionnaire}

This questionnaire was addressed to 33 respondents with 10 questions. This testing criterion is to compare with the Value or degree of freedom in this calculation is $0.296(\mathrm{DF}=33-2)$. Based on the calculation of this validity test, there are four questions that have a value lower than the value or degree of freedom. These questions are questions number 12, 13, 16 and 20. So the numbers will not be used in hypothesis testing.

Table 3: Validity Test of Self-Directed Learning

\begin{tabular}{|c|c|c|}
\hline Numbers & TheValue of & Explanation \\
\hline number11 & 0.349 & Valid \\
\hline number12 & 0.279 & Invalid \\
\hline number13 & 0.083 & Invalid \\
\hline number14 & 0.537 & Valid \\
\hline number15 & 0.422 & Valid \\
\hline number16 & 0.152 & Invalid \\
\hline number17 & 0.540 & Valid \\
\hline
\end{tabular}

\begin{tabular}{|c|c|c|}
\hline number18 & 0.496 & Valid \\
\hline number19 & 0.700 & Valid \\
\hline number20 & 0.239 & Invalid \\
\hline
\end{tabular}

\subsubsection{English Ability Questionnaire}

This questionnaire was given to 33 respondents with 10 questions. This testing criterion is to compare with the value or level of freedom in this calculation is 0.296 ( $\mathrm{DF}=33-2)$. Based on the calculation of this validity test, there are four questions that have a value lower than the value or level of freedom. These questions are questions number 24, 25, 27 and 29. So the numbers will not be used in hypothesis testing.

Table 4: Validity Test of English Ability

\begin{tabular}{|c|c|c|}
\hline Numbers & TheValue of & Explanation \\
\hline number21 & 0.423 & Valid \\
\hline number22 & 0.388 & Valid \\
\hline number23 & 0.529 & Valid \\
\hline number24 & 0.182 & Invalid \\
\hline number25 & 0.186 & Invalid \\
\hline number26 & 0.550 & Valid \\
\hline number27 & 0.291 & Invalid \\
\hline number28 & 0.635 & Valid \\
\hline number29 & 0.023 & Invalid \\
\hline number30 & 0.383 & Valid \\
\hline
\end{tabular}

\subsubsection{Reliability Tests}

\subsubsection{Novo Learning System Questionnaire}

The reliability instrument coefficient is intended to see the consistency of the answers given by respondents. The reliability coefficient in this test is 0.60 . Based on the calculations below, the novo learning questionnaire is declared reliable.

Table 5: Reliability Test of Novo Learning

\begin{tabular}{|c|c|}
\hline Cronbach's Alpha & N of Items \\
\hline 0.775 & 10 \\
\hline
\end{tabular}

\subsubsection{Self-Directed Learning Questionnaire}

The reliability instrument coefficient is intended to see the consistency of the answers given by respondents. The reliability coefficient in this test is 0.60 . Based on the calculations below, the novo learning questionnaire is declared reliable.

Table 6: Reliability Test Self-Directed Learning

\begin{tabular}{|l|l|}
\hline Cronbach's Alpha & N of Items \\
\hline 0.715 & 10 \\
\hline
\end{tabular}




\subsubsection{English Ability Questionnaire}

The reliability instrument coefficient is intended to see the consistency of the answers given by respondents. The reliability coefficient in this test is 0.60 . Based on the calculations below, the performance questionnaire is declared reliable.

Table 7: Reliability Test of English Ability

\begin{tabular}{|c|c|}
\hline Cronbach's Alpha & N of Items \\
\hline 0.681 & 10 \\
\hline
\end{tabular}

\section{RESULT}

\subsection{Test Result}

\subsubsection{Simultaneous Test (Test F)}

Simultaneous tests were used to answer the third hypothesis in this study. Is there a relationship between novo learning and self-directed learning toward English ability. Simultaneous test or F test is done by using regression analysis and multiple correlations for three variables, there is novo learning and self-directed learning as an independent variable and English ability as the dependent variable.

Table 8: Result of Simultant Test

\begin{tabular}{|c|c|c|c|c|c|}
\hline \multicolumn{6}{|c|}{ ANOVA $^{b}$} \\
\hline Model & $\begin{array}{c}\text { SumofSqu } \\
\text { ares }\end{array}$ & Df & $\begin{array}{l}\text { Mean } \\
\text { Square }\end{array}$ & $\mathrm{F}$ & Sig. \\
\hline 1 Regression & 74.046 & 2 & 37.023 & 24.959 & $0.000^{\mathrm{a}}$ \\
\hline Residual & 44.500 & 30 & 1.483 & & \\
\hline Total & 118.545 & 32 & & & \\
\hline \multicolumn{6}{|c|}{ a. Predictors: (Constant), selfdirected, novo } \\
\hline b. & ependent & ial & nglis & jility & \\
\hline
\end{tabular}

From the results of the simultaneous test, the coefficient of determination is 24,959 with a significance of 0.00 or 100 percent. Even though the value is 3.305. It means that it is greater than a significant value and smaller than alpha (0.05) so that the conclusion is to reject $\mathrm{H} 0$ and accept $\mathrm{H} 1$. There is a positive relationship between novo learning and self-directed learning on English ability. At least if novo learning and selfdirected learning improve, it will also increase English ability.

\subsubsection{Partial Test (T Test)}

Partial test or T test is used to answer the first and second hypotheses. The first hypothesis in this study states that there is a relationship between novo learning and English ability. And the second hypothesis states that there is a relationship between learning independence with achievement.

Table 9: Partial Test

\begin{tabular}{|c|c|c|c|c|c|c|}
\hline \multirow{2}{*}{\multicolumn{2}{|c|}{ Model }} & \multicolumn{2}{|c|}{$\begin{array}{c}\text { Unstandardized } \\
\text { Coefficients }\end{array}$} & \multirow[t]{2}{*}{$\begin{array}{l}\text { Standardize } \\
\text { Coefficients }\end{array}$} & \multirow[t]{2}{*}{$\mathrm{t}$} & \multirow[t]{2}{*}{ Sig. } \\
\hline & & B & $\begin{array}{c}\text { Std. } \\
\text { Error }\end{array}$ & & & \\
\hline 1 & (Constant) & 6.853 & 2.215 & & 3.094 & .004 \\
\hline \multicolumn{2}{|c|}{ novolearning } & .427 & .111 & .622 & 3.848 & .001 \\
\hline \multicolumn{2}{|c|}{ selfdirected } & .159 & .120 & .214 & 1.325 & .195 \\
\hline
\end{tabular}

The calculation of the regression coefficient shows the value of the constant coefficient is 6.853 with 3.094 with a significant 0.004 or 96 percent. The slope coefficient of novo learning is 0.427 with 3.848 with a significant value of 0.001 or 99 percent. In this test, if compared the value of $t$ and sig, the value is greater. And the importance is less than alpha (5\% or 0.05 ). The conclusion for the first hypothesis is to reject h0 and accept $\mathrm{h} 1$. This means that there is a positive and significant relationship between novo learning and English ability. This shows that higher novo learning will increase achievement. And if novo learning is lower, English ability will be low. The coefficient of independence of independent learning is 0.159 with 1.325 with a significant value of 0.195 . In this test, if compared the value of $t$ and sig, the value of $t$ is greater. And the importance is less than alpha (5\% or 0.05 ). The conclusion for the second hypothesis is to reject $\mathrm{h} 0$ and accept $\mathrm{h} 1$. This means that there is a positive and significant relationship between novo learning and English ability. This shows that higher learning independence will increase achievement. And if the lack of independence of learning, achievement will be low.

\subsection{System Result}

Based on the diagram of figure 3, the interest of the students to do assignment in the Novo Learning is very high and consistent. It shows how interesting this application and how responsible the students to learn by themselves. The percentage is $97.30 \%$ consistent meanwhile the students were excited during the test from course 1 to the progress test. 


\section{Placement Test, Course $1-6$}

\section{$120.00 \%$}

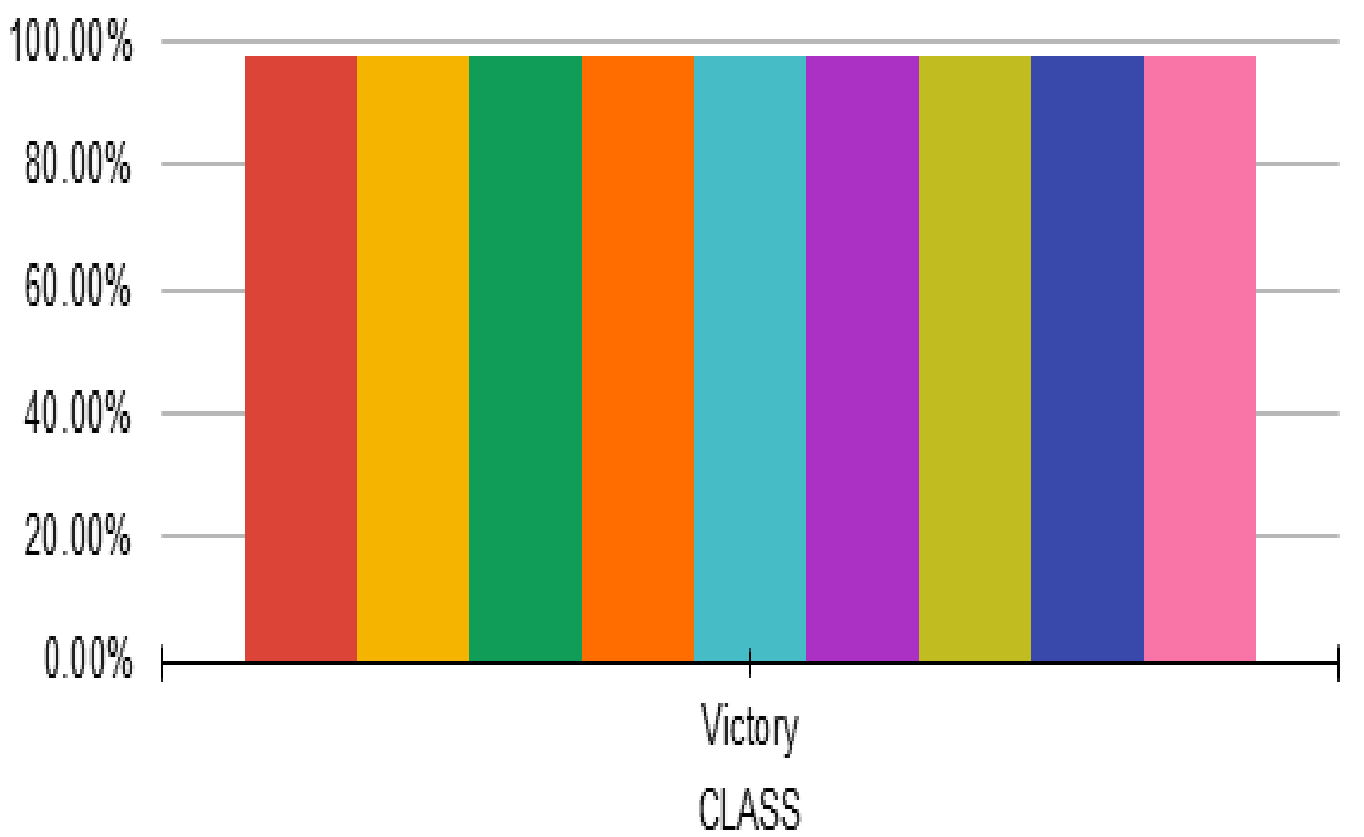

Course 1

Course 2

Course 3

Course 4

Course 5

- Course 6

Course 7

Course 8

- Progress Test

\section{Fig 3: Diagram Tabulation}

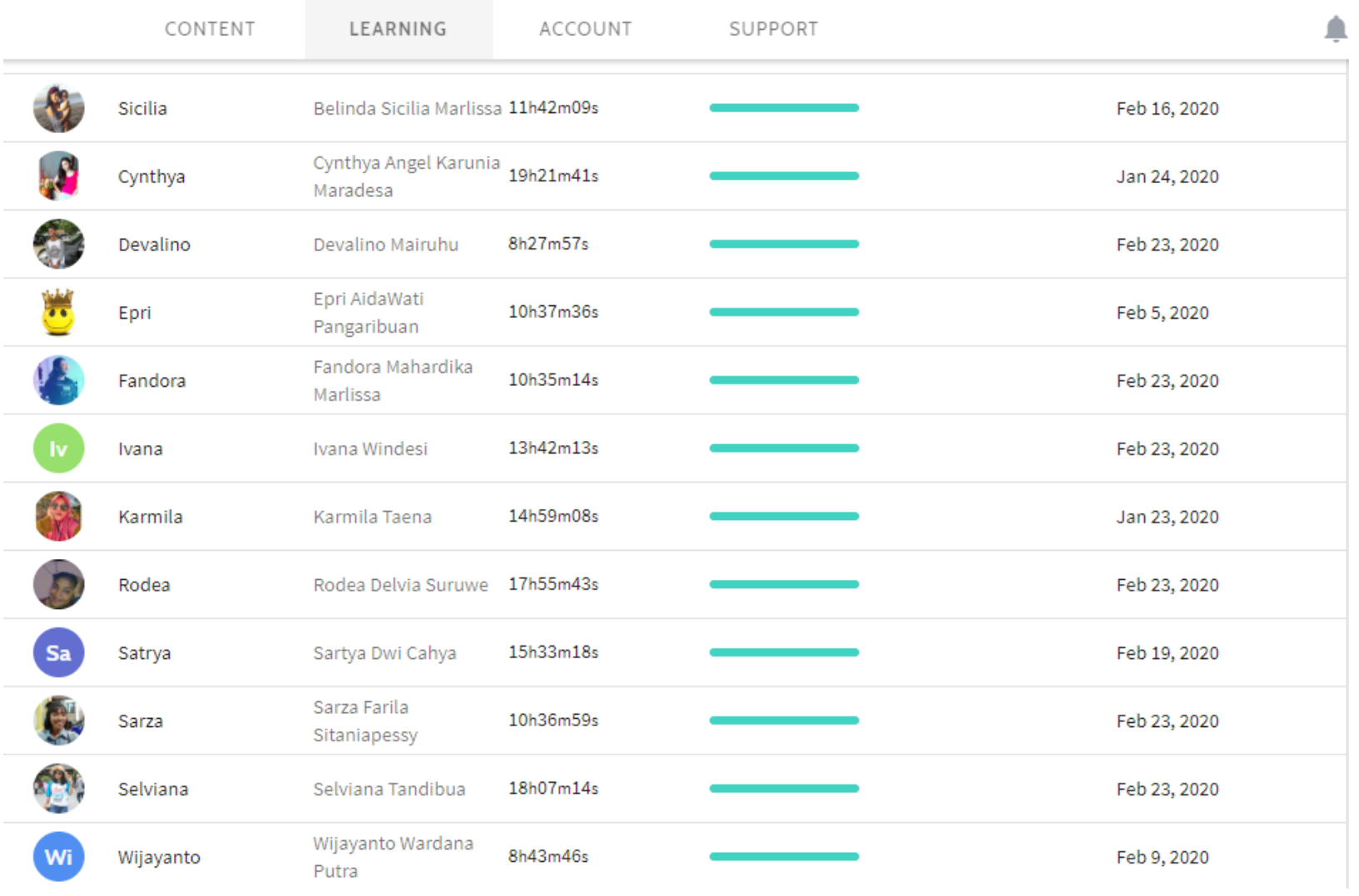

Fig 4: Final Test for Bronze Class 


\begin{tabular}{|c|c|c|c|c|}
\hline CONTENT & LEARNING & ACCOUNT & SUPPORT & \\
\hline Agnes & Agnes Dewi Setyarini & $8 \mathrm{~h} 53 \mathrm{~m} 59 \mathrm{~s}$ & 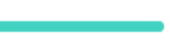 & Feb 11,2020 \\
\hline albertinamalak & Albertina Malak & $33 \mathrm{~h} 15 \mathrm{~m} 06 \mathrm{~s}$ & 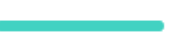 & Feb 18, 2020 \\
\hline Cevin & $\begin{array}{l}\text { Cevin William } \\
\text { Manullang }\end{array}$ & $10 \mathrm{~h} 13 \mathrm{~m} 48 \mathrm{~s}$ & 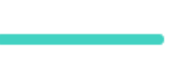 & $\operatorname{Jan} 22,2020$ \\
\hline Chintia & $\begin{array}{l}\text { Chintia Febriani } \\
\text { Metalmety }\end{array}$ & $11 \mathrm{~h} 28 \mathrm{~m} 53 \mathrm{~s}$ & 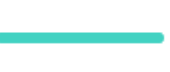 & Feb 2, 2020 \\
\hline christian & Christian Januar Ischah & k7h01m41s & 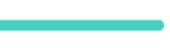 & Feb 21, 2020 \\
\hline Delia & Delia Makawimbang & $13 \mathrm{~h} 37 \mathrm{~m} 06 \mathrm{~s}$ & 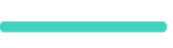 & Jan 24,2020 \\
\hline Dersiliana & $\begin{array}{l}\text { Dersiliana Jayanti } \\
\text { Todingan }\end{array}$ & $9 h 36 \mathrm{~m} 16 \mathrm{~s}$ & & Feb 5,2020 \\
\hline Dinda & Dinda Irdayani Soulisa & $10 \mathrm{~h} 02 \mathrm{~m} 01 \mathrm{~s}$ & 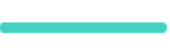 & Feb 21, 2020 \\
\hline Edwin & Edwin Mozes Sinaga & $10 \mathrm{~h} 31 \mathrm{~m} 26 \mathrm{~s}$ & 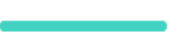 & $\operatorname{Jan} 23,2020$ \\
\hline evaarianti & Eva Arianti Polan & $26 \mathrm{~h} 52 \mathrm{~m} 54 \mathrm{~s}$ & 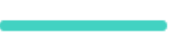 & Feb 2, 2020 \\
\hline $\operatorname{lin}$ & lin Rante & $14 \mathrm{~h} 24 \mathrm{~m} 58 \mathrm{~s}$ & 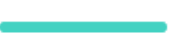 & $\operatorname{Jan} 30,2020$ \\
\hline Irsya & $\begin{array}{l}\text { Irsya Dilla } \\
\text { Cendrawansyah }\end{array}$ & $13 \mathrm{~h} 19 \mathrm{~m} 50 \mathrm{~s}$ & 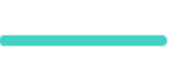 & $\operatorname{Jan} 27,2020$ \\
\hline
\end{tabular}

Fig 5: Final Test for Silver Class

Based on the last result found that there are 20 students who passed the passing grade 80 to get certificate or $60.6 \%$ of $100 \%$. This result could be higher if this program will do more than once

\section{CONCLUSION}

Based on data analysis, we can draw conclusions:

1. There is a positive relationship between novo learning and English ability. This can be proven by the result of significant product moment correlation analysis of $5 \%$. thitung >ttabel or 3,848>1,696.

2. There is no relationship between self-directed learning and English ability. This can be proven by the result of significant product moment correlation analysis of $5 \%$. thitung $<$ ttabel or $3,848<1,696$.

3. There is a positive relationship between novo learning and self-directed learning together on English ability. This can be proven by the result of significant product moment correlation analysis of 5\%. Fcount $>$ Ftable or 24959> 3.305.

\section{ACKNOWLEDGEMENTS}

The authors are delivering huge thankful to the experts who contributed a lot towards revision and development of this paper

\section{REFERENCES}

[1] Boholano, H. Smart social networking: 21st century teaching and learning skills. 2017. Research in Pedagogy, 7(1), 21-29. DOI: 10.17810/2015.45.
[2] Tjandrawina, R.R. Industri 4.0: Revolusi industry abad ini dan pengaruhnya pada bidang kesehatan dan bioteknologi. 2016. JurnalMedicinus, Vol 29, Nomor 1, Edisi April.

[3] Salmerón, L., García, A., Abarca, E. V. 2018.The Development of Adolescents' Comprehensionbased Internet Reading Activities. Learning and Individual Differences, 61: 31- 39 .

[4] Salmerón, L., García, A., Abarca, E. V. 2018. The Development of Adolescents' Comprehensionbased Internet Reading Activities. Learning and Individual Differences, 61: 31- 39 .

[5] Sanjaya. 2013. Penelitian Pendidikan, Jenis, Metode dan Prosedur. Jakarta: KencanaPrenada Media Group.

[6] Darmaji, Kurniawan, D. A., Parasdila, H., \&Irdianti. 2018. Description of Science Process Skills' Physics Education Students at Jambi University in Temperature and Heat Materials. The Educational Review, USA, 2(9), 485-498,

[7] Astalini, Kurniawan, D. A., Perdana, R., \& Kurniawan, W. 2019. Identification Attitudes of Learners on Physics Subject. EST Journal of Educational Science and Technology.5(1), 39-48.

[8] Sezer, S., and Ertu, E. 2019. School Happiness: A Scale Development and Implementation Study. Eurasian Journal of Educational Research. 79: 167-190.

[9] Laine, E., Veermans, M., Lahti, A., and Veermans, K. 2017. Generation of student interest in inquiry-based 
mobile learning environment. Frontline Learning Research 5(4), 1-13.

[10] Fisher, King, \&Tague. 2001. Development of a SelfDirected Learning Readiness Scale for Nursing Education. Sydney: Published online.

[11] Guglielmino, L. Madsen. 2013. The Case for Promoting Self-Directed Learning in Formal Educational Institutions.SA-eDUC JOURNAL Volume 10, Number 2, October 2013.

[12] Suryana. 2010. Metodologi Pengajaran-Buku Ajar
Perkuliahan. Universitas Pendidikan Indonesia.

[13] Musfiqon, H.M. 2012. Panduan Lengkap Metodologi Penelitian Pendidikan.Jakarta: Prestasi Pustakaraya.

[14] Sudjono. 2010. Pengantar Statistik pendidikan. Jakarta: Rineka Cipta.

[15] Sujarweni and Endrayanto. 2012. Statistika Untuk Penelitian. Yogyakarta: Graha Ilmu.

[16] Nazir. 2011. Metodologi Penelitian.Bogor: Ghalia Indonesia. 